are seeking, I believe, without exception, to advance the material interests of those whom they represent. The claims which you put forward on behalf of experimental research would be wholly unselfish. They would be for work in the common interest, in the interest of mankind. In the report for the year there is a very long list of work done in different departments of scientific research with small sums like $\mathrm{rol}$. or so given out of your small Government grant to meet expenses. It is a list capable of indefinite expansion, and indicates work that might be done on a larger and more fruitful scale. Undertakings like the Research Commission to Uganda may well return their cost a hundred-fold, and I venture to suggest that an appeal should be made to those in charge of the Development Fund to give a wider scope to your disinterested and most beneficent activities."

\section{COTTON GROWING WITHIN THE BRITISH EMPIRE.}

THE British Cotton Growing Association was inaugurated in 1902 with the object of extending the cultiwation of cotton throughout parts of the British Empire where conditions should prove suitable. During the eight years that have elapsed, valuable information has been acquired by means of pioneering expeditions and experimental cultivation in more remote parts of the Empire and from the results yielded by private undertakings that have been liberally assisted with technical advice and financial means. As it was announced a year ago, the inquiry stage is practically completed, and it has been decided to concentrate the main efforts of the association on the work in Nigeria, Uganda, Nyasaland, and the West Indies. The present state and future outlook of the cotton industry are therefore opportunely summarised in the address delivered by Mr. J. H. Reed before the Royal Geographical Society on Monday, December 5 .

The principal supply of raw material from the United States of America has increased during the last quarter of a century from seven to thirteen million bales per annum; the output of India may reach a total of five million bales, but most of it is short-stapled, and Egypt supplies somewhat more than a million bales. Against this has to be placed the demand for cotton, which in this country has remained nearly stationary, at a total of three million bales, while the United States of America now require nearly five million bales, and the countries of Europe absorb six million bales. With regard to other sources of supply, the class of cotton grown in the West Indies is of good quality, but owing to the limited area the amount produced can never be large, so that the most hopeful fields for the labours of the association lie in West and Central Africa. The colony of Lagos bids fair to produce an appreciable quantity of cotton; the extension of the industry in Nyasaland, where a superior type of upland is a prominent variety, is distinctly encouraging, and the late High Commissioner of Uganda has reported upon the favourable climate and conditions, as well as the eagerness of the natives in that Protectorate for taking up cotton cultivation. In the Sudan there are large areas of suitable land near the junctions of the Atbara and the Blue Nile with the main stream, in the province of Berber, and on the plains between the converging courses of the Blue and White Nile. Of the prospects in Rhodesia it is too early to pronounce a definite opinion, but the experimental work gives promise of the possibility of a native industry being developed under European guidance.

\section{PESTS OF FRUIT TREES.}

A FRUIT-GROWERS' conference was held, in conjuncA tion with the National Fruit-growers' Federation, at persons, mostly fruit-growers in Kent, attended. The papers of scientific interest were read by Mr. F. V. Theobald, vice-principal and entomologist at the college, and by Mr. E. S. Salmon, mycologist.

Mr. Theobald dealt with the damage done to fruit trees by Thrips. At least three species of Thrips damage fruit trees and bushes, the commonest, apparently, being Euthrips pyri, Daniel. This species is found on apple, NO. 2 I 45 , VOL. 85] pear, plum, raspberry, loganberry, and strawberry. The winged adult females first enter the opening buds, and then by means of their conical mouths so lacerate the young tissue that the buds die soon after opening. Leaves and blossoms are also attacked. The ova are laid in slits cut by the female in the young leaves and strigs. The pale, wingless larvæ attack the young fruitlets, which either crack and drop off prematurely, or, if less injury is done on somewhat larger fruitlets, the abrasions lead to the formation of areas or scars, which disfigure or even entirely ruin the fruit. The larvæ when mature enter the soil, and there produce a pupal stage with long wing buds, and the winged Thrips appear again. The winter is passed in the larval stage in the earth. Treatment with soil fungicides appears to be the only practicable method of dealing with this fruit pest.

Mr. E. S. Salmon dealt with the epidemic outbreak of Eutypella prunastri, which during the past few years has destroyed thousands of young fruit trees in certain districts in Kent, Herefordshire, and Worcestershire. In one case near Canterbury 1200 "Victoria" plums, 300 " Czars," and 50 "Monarchs" were attacked and killed. The variety of plum called " Rivers Early Prolific" appears to possess powers of resistance to Eutypella. Young apple and cherry trees have also been destroyed by this disease.

The life-history of the apple "scab" fungus (Venturia inaequalis) was dealt with, and instances were given which showed that this disease can be successfully prevented by the use of the fungicide known as "Bordeaux mixture." The statement sometimes made by growers that the "scab" fungus can infect and spread on stored apples is due to an error of identification. Recent investigations made by Mr. Salmon show that we have in this country a species of Leptothyrium, not hitherto reported, which attacks apples both on the tree and in the fruit-room, and forms sooty-looking spots on them. It is probably the species L. pomi, well known in America as the cause of the "sooty blotch" and "fly speck" diseases.

Evidence was adduced as to the different degrees of susceptibility to injury from Bordeaux mixture shown by different varieties of English apples.

\section{THE DISCOVERY OF NEPTUNE.}

\section{LEVERRIER'S LETTER TO GALLE.}

WHILE so much has been written about the dramatic discovery of the outermost known planet, it is strange that until quite recently the full text of the letter in which Leverrier announced to Galle the results of his wonderful investigations appears not to have been published.

A copy of this historic document was communicated by its recipient to Dr. See about five years ago, for use in a work on the planetary system which the latter was then preparing. But the death of Galle in July last has prompted Dr. See to anticipate the issue of his work by publishing the letter by itself in No. 8, vol. xviii., of Popular Astronomy (October, p. 475). The ostensible reason for writing to Galle was to acknowledge the receipt of the memoir which the latte: had prepared, and in which he had reduced and critically discussed Roemer's synopsis of three days' work, which alone escaped the conflagration of 1728 , under the title " $O$. Roemer's Triduum Observatorium Astronomicarum a. I706 Institutorum" (Berlin, 1845). The letter runs as follows:-

\section{“ MONSIEUR}

"Paris, le I8 septembre 1846 .

"J'ai lu avec beaucoup d'intérêt et d'attention la réduction des observations de Roemer, dont Vous avez bien voulu m'envoyer un exemplaire. La parfaite lucidité de Vos explications, la complète rigueur des résultats que Vous nous donnez, sont au niveau de ce que nous devions attendre d'un aussi habile astronome. Plus tard, Monsieur, je Vous demanderai la permission de revenir sur plusieurs points qui m'ont intéressé, et en particulier sur les observations de Mercure qui y sont renfermées. Aujourd'hui, je voudrais obtenir de l'infatigable observateur qu'il voulut bien consacrer quelques instants à l'examen d'une région du Ciel, où il peut rester une Planète à découvrir. C'est la théorie d'Uranus qui m'a 